\title{
Distance Learning Environment and Intrinsic Motivation of Students of Social Science Education, State University of Jakarta
}

\author{
Rizky Nurisriyani ${ }^{1}$, Dian Alfia Purwandari ${ }^{2}$, Sujarwo ${ }^{3 *}$ \\ ${ }^{123}$ (Program Studi Pendidikan IImu Pengetahuan Sosial /Universitas Negeri Jakarta, Indonesia) \\ * Corresponding Author. E-mail: ${ }^{1}$ rizkyriyani15@gmail.com
}

Receive: $13 / 08 / 2021$

Accepted: 23/09/2021

Published: 08/10/2021

\begin{abstract}
Abstrak
Pembelajaran Jarak Jauh di era pandemi Covid-19 menjadi sebuah alternatif yang digunakan oleh setiap univesitas agar kegiatan proses pembelajaran terus berjalan meskipun hanya tatap maya agar tujuan pendidikan tercapai secara efektif dan efisien. Penelitian ini bertujuan untuk menganalisis pengaruh Lingkungan Pembelajaran Jarak Jauh terhadap Motivasi Intrinsik dalam belajar pada mahasiswa program studi Pendidikan IPS. Metode yang digunakan dalam penelitian ini adalah penelitian metode kuantitatif dengan teknik pengambilan sampel yang digunakan adalah cluster sampling. Populasi yang digunakan pada penelitian ini adalah mahasiswa Pendidikan IPS angkatan 2018-2020 sebanyak 252 mahasiswa, sedangkan yang digunakan untuk sampel sebanyak 155 responden. Berdasarkan hasil uji $t$ diperoleh hasil $t_{\text {hitung }} 8,384>t_{\text {tabel }} 1,975$ yang artinya terdapat pengaruh variabel Lingkungan Pembelajaran Jarak Jauh terhadap Motivasi Intrinsik dalam belajar pada mahasiswa program studi Pendidikan IPS. Hal tersebut diperkuat dengan perolehan hasil uji koefisien determinasi sebesar $31,3 \%$.
\end{abstract}

Kata Kunci: Lingkungan Pembelajaran Jarak Jauh, Motivasi Intrinsik, Pembelajaran.

\section{Abstract}

Distance Learning in the Covid-19 pandemic era has become an alternative used by every university so that the learning process activities continue even though it is only face-to-face so that educational goals are achieved effectively and efficiently. This study aims to analyze the effect of the Distance Learning Environment on Intrinsic Motivation in learning for students of the Social Sciences Education study program. The method used in this research is quantitative research method with the sampling technique used is cluster sampling. The population used in this study were 252 social studies education students batch 2018-2020, while the sample used was 155 respondents. Based on the results of the t-test, the results obtained are t-count $8.384>t$-table 1.975, which means that there is an influence of the Distance Learning Environment variable on Intrinsic Motivation in learning in students of the Social Sciences Education study program. This is reinforced by the acquisition of the coefficient of determination test results of $31.3 \%$.

Keywords: Distance Learning Environment, Intrinsic Motivation, Learning.

\section{PENDAHULUAN}

Pendidikan merupakan suatu hal penting bagi setiap individu untuk dapat meningkatkan kualitas intelektual serta mengembangkan potensi dan menjadikan individu yang memiliki budi pekerti juga moral yang baik (Elfian et.al.,2017). Potensi yang dimiliki oleh masing-masing individu dapat dikembangkan melalui kegiatan pembelajaran baik dalam aspek pengetahuan, sikap maupun keterampilan melalui pendidikan tersebut, sehingga untuk mewujudkannya dibutuhkan motivasi belajar yang menjadi salah satu faktor penting agar kegiatan pembelajaran dapat terlaksana dengan efektif (Rista \& Ariyanto, 2018).

Pelaksanaan kegiatan pembelajaran di Perguruan Tinggi memberikan kebebasan kepada mahasiswa untuk dapat menciptakan suasana belajar, serta memberikan kesempatan untuk memperdalam pengetahuannya secara mandiri yang 
didampingi oleh peran dosen sebagai fasilitator selama proses pendidikan berlangsung (Aiyub, 2015). Motivasi belajar merupakan suatu hal penting untuk mendorong mahasiswa untuk dapat meningkatkan kemampuan serta kualitas belajarnya (Emda, 2018). Motivasi belajar menjadi pusat daya penggerak mahasiswa sekaligus petunjuk arah dalam kegiatan belajarnya, sehingga mahasiswa dapat bertindak dalam kegiatan belajar sesuai dengan tujuan yang hendak dicapainya (Agustina \& Danang, 2020).

Mahasiswa yang memiliki motivasi tinggi akan berupaya untuk meningkatkan keaktifannya dalam kegiatan pembelajaran serta mampu mengelola waktu belajarnya secara mandiri, sehingga mahasiswa akan terus berusaha untuk meningkatkan kemampuannya dalam meningkatkan prestasi belajarnya (Mendari \& Kewa, 2015). Hal tersebut sejalan dengan pernyataan Dai dan Stenberg dalam (Handayani, 2017) bahwa motivasi belajar merupakan suatu hal yang bersifat dinamis dan kontekstual yang berhubungan dengan strategi kegiatan pembelajaran yang dapat dikontrol oleh diri masing-masing mahasiswa.

Motivasi belajar dapat dirangsang oleh beberapa faktor baik secara intrinsik maupun ekstrinsik, salah satu faktor intrinsik yaitu berasal dari dalam diri individu seperti adanya keinginan untuk mencapai suatu keberhasilan belajar, sedangkan faktor ekstrinsik yaitu adanya lingkungan belajar yang kondusif (Emda, 2018). Penelitian ini terfokus pada motivasi intrinsik. Menurut Hamalik dalam (Azis,2017) motivasi intrinsik merupakan dorongan yang timbul berdasarkan kebutuhan serta tujuan yang dimiliki oleh peserta didik dalam melaksanakan kegiatan belajar. Adapun indikator motivasi intrinsik menurut Uno dalam (Ayu, 2017) terdiri atas : 1) Hasrat dan keinginan berhasil,2) Kebutuhan dan dorongan belajar, 3) Harapan akan cita-cita. Motivasi intrinsik terfokus pada kegiatan yang dilakukan mahasiswa dengan bentuk kesenangan dan kepuasan yang berasal dari dalam dirinya, mahasiswa yang memiliki motivasi intrinsik tinggi tentu memiliki keinginan dan akan terus berusha untuk mengembangkan potensi yang dimilikinya agar dapat mencapai tujuan atau prestasi belajarnya (Handayani, 2017).

Dalam kegiatan pembelajaran, lingkungan belajar yang nyaman dan kondusif juga akan menciptakan suasana belajar yang lebih baik, sehingga semangat belajar dan konsentrasi seseorang dapat lebih fokus ketika proses pembelajaran berlangsung (Damanik, 2019). Lingkungan pembelajaran dalam kelas yang kondusif dapat menciptkan proses kegiatan pembelajaran yang berkualitas dan bermakna. Namun sejak munculnya penyebaran wabah virus Covid-19, terhitug sejak awal bulan Maret 2020, seluruh kegiatan yang dilakukan di luar rumah yang bersifat kerumuman dibatasi dengan kebijakan pemerintah untuk mencegah penularan virus Covid-19, sejak itu pula Kementerian Pendidikan dan Kebudayaan menghimbau agar seluruh kegiatan pembelajaran di Perguruan Tinggi di Indonesia untuk dilaksanakan di rumah masing-masing secara daring. Pendidikan yang dilakukan dengan pembelajaran konvensioal secara bertatap muka kini mengalami perubahan secara drastis dengan model pembelajaran yang hanya dilakukan dengan bertatap maya secara online yang ditunjang oleh bebarapa platform daring seperti WhatsApp, Google Meet, Zoom, Google Clasroom, dan berbagai media online lainnya yang dapat menghubungkan dosen dengan mahasiswa agar proses kegiatan belajar tetap terlaksana sebagai mestinya (Hakim \& Mulyapradana, 2020).

Pembelajaran Jarak Jauh menjadi sebuah alternatif yang digunakan oleh setiap universitas agar kegiatan proses belajar terus berjalan meskipun hanya secara daring agar tujuan pendidikan tercapai secara efektif dan efisien (Argaheni, 2020). Berdasarkan hasil observasi yang dilakukan oleh peneliti yang dilaksanakan pada bulan Maret sampai 
Desember 2020, menunjukkan bahwa dalam pelaksanaan kegiatan Pembelajaran Jarak Jauh yang dilakukan oleh dosen dan mahasiswa Program Studi Pendidikan IPS menggunakan platform atau media online seperti zoom, Google Meet, WhatsApp Gorup, dan Goole Clasroom sebagai wadah untuk berdiskusi, memberikan serta mengumpulkan tugas.

Kesulitan umum dalam pelaksanaan Pembelajaran Jarak Jauh disebabkan karena cukup sulit merubah kebiasaan yang dilakukan oleh dosen dan mahasiswa yang biasanya melakukan kegiatan belajar di dalam kelas menjadi interaksi secara tatap maya dengan memanfaatkan komponen dalam melaksanakan kegiatan pembelajaran (Utami, 2020). Selain metode pembelajaran yang dapat meningkatkan semangat belajar mahasiswa, lingkungan belajar yang kondusif juga menjadi faktor yang dapat memotivasi mahasiswa dalam melaksanakan kegiatan proses pembelajaran (Suwastika, 2017).

Lingkungan Pembelajaran Jarak Jauh merupakan kondisi atau keadaan sekitar yang memungkinkan peserta didik dapat memecahkan permasalahan dan memiliki akes untuk mendapatkan materi yang dapat membantu mencapai tujuan dalam kegiatan belajar (Ozerem \& Akkoyunlu, 2015). The United States Distance Learning Association (USDLA) dalam (Koçoğlu \& Tekdal, 2020) menyatakan bahwa Pembelajaran Jarak Jauh merupakan akses dalam pendidikan yang dilaksanakan dengan menggunakan teknologi seperti audio visual, komputerisasi, multimedia dan lain-lainnya. pada penelitian ini terdapat 6 indikator lingkungan pembelajaran Jarak Jauh menurut (Walker et.al.,2020) antara lain: 1) Interaksi dosen dengan mahasiswa 2) Interaksi mahasiswa dengan mahasiswa, 3) Pengembangan kompetensi pribadi, 4) pembelajaran autentik, 5) Pembelajaran Aktif, dan 6) Kemandirian mahasiswa.

Pelaksanaan kegiatan Pembelajaran Jarak Jauh memberikan dampak positif dan negatif yang beriringan. pembelajaran Jarak Jauh dapat membentuk kemandirian mahasiswa untuk memperdalam ilmu pengetahuan serta memberikan kepada mahasiswa yang biasanya tidak banyak bicara di kelas mendapatkan ruang untuk menyampaikan pendapatanya melalui tulisan, namun meski demikian dalam kegiatan pembelajarn Jarak Jauh tidak seluruh mahasiswa sukses dalam kegaitan pembelajaran karena faktor lingkungan pembelajaran dan perbedaan karakteristik, oleh karena itu banyak mahasiswa yang kurang memahami materi, sebagian mahasiswa menjadi pastif, dan ketetbatasan internet dapat menghambat terlaksananya kegiatan proses pembelajaran (ochtavia Yolanda Putri, 2020).

Berdasarkan uraian diatas maka adapaun rumusan masalah penelitian ini adalah "Apakah terdapat pengaruh Lingkungan Pembelajaran Jarak Jauh Terhadap Motivasi Intrinsik Dalam Belajar Mahasiswa?"

\section{METODELOGI PENELITIAN}

\section{Metode Penelitian}

Penelitian ini dilakukan dengan menggunakan metode penelitian kuantitatif, yakni kegiatan pengumpulan, pengolahan, analisis dan penyajian data yang dilakukan secara sistematis dan objektif untuk memecahkan suatu persoalan atau menguji suatu hipotesis untuk mengembangkan prinsip-prinsip umum (Duli, 2019). Pendekatan kuntitatif dalam penelitian ini untuk mengetahui ada atau tidaknya pengaruh Lingkungan Pembelajaran Jarak Jauh (X) dan Motivasi Intrinsik (Y).

\section{Populasi dan Sampel}

Populasi dalam penelitian ini merupakan mahasiswa Program Studi Pendidikan IPS, Fakultas Ilmu Sosial, Universitas Negeri Jakarta angkatan 2018, 2019 dan 2020 yang berjumlah sebanyak 252 mahasiswa. Sampel merupakan bagian dari jumlah yag dimiliki oleh populasi dalam sebuah penelitian, adapun metode pengambilan sampel yang dipakai dalam penelitian ini adalah teknik area (Cluster) sampling yang merupakan teknik pengambilan 


\begin{tabular}{cc}
\hline Kategori & Rumus \\
\hline Rendah & $X<M-1 S D$ \\
\hline Sedang & $M i-1 S D \leq X<M+S D$ \\
\hline Tinggi & $x \geq M+1 S D$ \\
\hline
\end{tabular}

sampelnya berdasarkan daerah populasi yang telah ditetapkan (Sugiyono, 2013). Adapun sampel yang digunakan berdasarkan hasil perhitungan menggunakan rumus slovin dengan tingkat error 5\% dari jumlah keseluruhan populasi terdapat 155 responden dijadikan sebagai sampel penelitian. Berikut ini data sampel penelitian berdasarkan pembagian sub kelompok antara lain sebagai berikut:

Tabel 1. Sampel Penelitian

\begin{tabular}{ccc}
\hline No & Angkatan & Jumlah \\
\hline 1 & 2018 & 81 Mahasiswa \\
\hline 2 & 2019 & 78 Mahasiswa \\
\hline 3 & 2020 & 93 Mahasiswa \\
\hline & Jumlah & 252 Mahasiswa \\
\hline
\end{tabular}

\section{Instrumen Penelitian}

Instrumen penelitian merupakan sebuah alat ukur yang digunakan dalam pengumpulan data untuk mengukur nilai variabel yang diteliti dengan tujuan penggunaannya dapat menghasilkan data kuantitaitf yang akurat, maka setiap instrumen harus memiliki skala (Sugiyono,2013). Instrumen dalam penelitian ini menggunakan angket atau kuesioner bersifat tertutup dengan menggunakan skala likert 1-4.

\section{Teknik Analisi Data}

Teknik analisis data pada penelitian ini yaitu dengan teknik analisis deskripsi yang dideskripsikan dengan membuat kategorisasi masing-masing dimensi variabel. Menurut Azwar dalam (Akhtar, 2018) kategorisasi bertujuan untuk melihat sebaran data penelitian apakah berada pada tingkat rendah, sedang atau tinggi. Adapun tabel rumus kategorisasi sebagai berikut:
Adapun uji analisis prasyarat yaitu menggunakan uji normalitas. Uji hipotesis yang digunakan dalam penelitian ini terdiri antara lain : 1) Uji Koefisien Korelasi, 2) Uji-t, 3) Persamaan Regresi Sederhana, dan 4) Uji Koefisien Determinasi.

\section{HASIL DAN PEMBAHASAN}

Hasil

Penelitian ini dilakukan bertujuan untuk menjelaskan pengaruh Lingkungan Pembelajaran Jarak Jauh terhadap Motivasi Intrinsik dalam belajar mahasiswa program studi Pendidikan IPS angkatan 2018-2020. Berdasarkan data penelitian yang telah dikumpulkan dan diolah, adapun hasil perhitungan kategorisasi dimensi dari masingmasing variabel didapatkan perolehan data sebagai berikut:

Tabel 3. Distribusi Kategorisasi Dimensi Variabel

\begin{tabular}{lcc}
\hline Variabel & Dimensi & $\begin{array}{c}\text { Kategorisas } \\
\text { i }\end{array}$ \\
\hline Motivasi & Motivasi & $87,1 \%$ \\
Intrinsik & Intrinsik & $($ Sedang) \\
\hline Lingkungan & Interaksi & $82,6 \%$ \\
Pembelajara & & $($ Sedang) \\
\cline { 2 - 3 } n Jarak Jauh & Pengembangan & $63,2 \%$ \\
& Diri & (Tinggi) \\
\hline
\end{tabular}

Sumber: Data peneliti yang diolah tahun 2021

Berdasarkan tabel diatas dapat dilihat perolehan data hasil perhitungan kategorisasi pada dimensi motivasi intrinsik pada variabel motivasi intrinsik sebesar $87,1 \%$ berada pada kategori sedang.

Pada variabel Lingkungan Pembelajaran Jarak Jauh terdapat dua dimensi yang terdiri atas dimensi interaksi dan dimensi pengembangan diri. Dimensi interaksi memperoleh hasil persentase sebesar $86,2 \%$ berada pada kategori sedang sedangkan dimensi pengembangan diri memperoleh hasil perhitungan dengan persentase sebesar $63,2 \%$ berada pada kategori tinggi. 
Untuk mengetahui apakah distribusi data yang telah dikumpulkan berdistribusi normal atau tidak, maka dilakukaknnya uji normalitas sebagai uji prasyarat analisis. Uji normalitas yang dilakukan menggunakan uji One Sample Kolmogorov-Smirnov dengan bantuan program SPSS Versi 24. Adapun hasil perhitunganya sebagai berikut:

Tabel 4. Hasil Uji Normalitas

\begin{tabular}{|c|c|c|}
\hline \multicolumn{3}{|c|}{ One-Sample Kolmogorov-Smirnov Test } \\
\hline \multicolumn{3}{|c|}{$\begin{array}{c}\text { Unstandardized } \\
\text { Residual }\end{array}$} \\
\hline $\mathbf{N}$ & & 155 \\
\hline \multirow{2}{*}{$\begin{array}{l}\text { Normal } \\
\text { Parameters } \\
\text { a.b }\end{array}$} & Mean & .0000000 \\
\hline & $\begin{array}{l}\text { Std. } \\
\text { Deviation }\end{array}$ & 3.40221094 \\
\hline \multirow{3}{*}{$\begin{array}{l}\text { Most } \\
\text { Extreme } \\
\text { Differences }\end{array}$} & Absolute & .038 \\
\hline & Positive & .029 \\
\hline & Negative & -.038 \\
\hline \multicolumn{2}{|c|}{ Test Statistic } & .038 \\
\hline \multicolumn{2}{|c|}{ Asymp. Sig. (2-tailed) } & $200^{\mathrm{cd}}$ \\
\hline
\end{tabular}

Sumber: Data Peneliti yang diolah tahun 2021

Berdasarkan hasil uji normalitas diperoleh nilai signifikansi sebesar 0,200 lebih besar dari 0,05.

Hasil uji hipotesis Lingkungan Pembelajaran Jarak Jauh terhadap Motivasi Intrinsik diperoleh hasil perhitungan uji korelasi koefisien yang dilakukan menggunakan uji korelasi Pearson Product Moment dengan perolehan nilai signifikansi 0,000 lebih kecil dari 0,05 $(0,000<0,05)$ dengan nilai $r$ sebesar 0,559. Berdasarkan perhitungan hasil uji $t$, besarnya pengaruh variabel $\mathrm{X}$ terhadap variabel $\mathrm{Y}$ diperoleh $t_{\text {hitung }}$ sebesar 8,384 dengan nilai tabel dengan $\mathrm{N}=155$ yaitu sebesar 1,975. Jika dilihat berdasarkan persamaan regresi sederhana diperoleh persamaan sebagai berikut:

$$
Y=9,358+0,206 X
$$

Dilihat berdasarkan hasil uji koefisien determinasi besarnya pengaruh Lingkungan Pembelajaran Jarak Jauh terhadap Motivasi Intrinsik yaitu sebesar $31,3 \%$.

\section{Pembahasan}

Berdasarkan hasil perhitungan kategorisasi pada dimensi motivasi intrinsik diperoleh hasil sebesar $87,1 \%$ yang menunjukkan bahwa sebagian besar responden melakukan kagiatan belajar didorong oleh keinginan yang berasal dari dalam diri masing-masing mahasiswa karena adanya hasrat keinginan dan berhasil dalam melakukan kegiatan pembelajaran, sehingga mahasiswa berusaha untuk aktif dalam mengikuti kegiatan pembelajaran agar dapat memahami serta menguasai materi yang dipelajari, meskipun pembelajaran hanya dilakukan secara daring mahasiswa terus berusaha agar mendapatkan hasil belajar yang maksimal, serta melaksanakan kegiatan pembelajaran sebagai kebutuhan untuk mencapai suatu yang dicita-citakan.

Pada variabel Lingkungan Pembelajaran Jarak Jauh terdapat dua dimensi yang terdiri atas dimensi interkasi dan dimensi pengembangan diri. Pada dimensi interaksi diperoleh hasil perhitungan sebesar 82,6\% yang menunjukkan bahwa mayoritas mahasiswa menjalin interkasi yang cukup kuat. Dosen menanggapi diskusi terkait materi pembelajaran serta tugas yang dikerjakan oleh mahasiswa, sehingga dapat membantu mahasiswa dalam kegiatan belajarnya, begitupun interaksi mahasiswa dengan mahasiswa lainnya dengan memanfaatkan media online sehingga komunikasi interaktif tetap terjalin baik untuk berdiskusi mengenai materi pembelajaran maupun untuk saling berbagi informasi lainnya selama melaksanakan kegiatan Pembelajaran Jarak Jauh. Sedangkan pada dimensi pengembangan diri diperoleh hasil sebesar 63,2\% yang menunjukkan bahwa sebagian besar responden mampu mengikuti kegiatan Pembelajaran Jarak Jauh secara aktif yang mampu meningkatkan semangat belajar baik dalam kegiatan diskusi mengenai materi pembelajaran maupun memecahkan permasalahan dalam konteks pembelajaran. Sebagian mahasiswa juga mampu mengembangkan kemampuan yang dimilikinya secara kompeten, serta mampu mengelola kegiatan belajar secara mandiri 
selama melaksanakan kegiatan Pembelajaran Jarak Jauh.

Berdasarkan hasil uji korelasi pada penelitian ini digunakan uji korelasi Pearson Product Moment dengan perolehan nilai signifikansi 0,000 lebih kecil dari 0,05 $(0,000<$ $0,05)$ hal tersebut menunjukan bahwa variabel Lingkungan Pembelajarn Jarak Jauh dengan Variabel Motivasi Intrinsik berkorelasi dan perolehan nilai $r$ sebesar 0,559 jika dilihat berdasarkan tabel interpretasi (Sugiyono, 2011) nilai $r$ tersebut masuk pada kategori cukup.

Berdasarkan hasil uji t diperoleh hasil

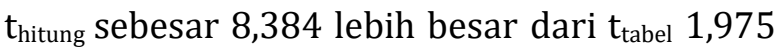
$(8,384>1,975)$, artinya variabel Lingkungan Pembelajaran Jarak Jauh berpengaruh terhadap variabel Motivasi Intrinsik, maka dapat diambil keputusan bahwa HO ditolak dan H1 diterima. Jika dilihat berdasarkan persamaan regresi sederhana di peroleh $\mathrm{Y}=$ 9,358 + 0,206X pengaruh variabel Lingkungan Pembelajaran Jarak Jauh terhadap Motivasi Intrinsik bersifat positif, yang artinya apabila variabel Lingkungan Pembelajaran Jarak Jauh naik maka variabel Motivasi Intrinsik juga naik.

Pada era wabah pandemi Covid-19 menjadikan Pembelajaran Jarak Jauh sebagai alternatif agar kegiatan dalam bidang pendidikan tetap terlaksana secara optimal. Adanya Lingkungan Pembelajaran Jarak Jauh yang kondusif dapat mendorong semangat belajar mahasiswa yang dapat meningkatkan motivasi intrinsik mahasiswa dalam kegiatan belajar. Sehingga hipotesis yang ditemukan pada penelitian ini adalah terdapat pengaruh yang positif dan signifikan antara Lingkungan Pembelajaran Jarak Jauh terhadap Motivasi Intrinsik dalam belajar pada mahasiswa program studi pendidikan Ilmu Pengetahuan Sosial angkatan 2018-2020.

Sejalan dengan hasil penelitian yang dilakukan oleh (Farihin, 2014) bahwa lingkungan belajar merupakan komponen penting dalam sebuah dunia pendidikan sehingga secara tidak langsung dapat mempengaruhi motivasi belajar, adanya lingkungan pembelajaran yang kondusif dapat meningkatkan motivasi belajar sehingga memudahkan berlangsungnya transfer ilmu pengetahuan kepada mahasiswa. Hal tersebut diperkuat juga oleh hasil penelitian (Damanik, 2019) bahwa lingkungan belajar memang memegang peran yang sangat penting dan berpengaruh terhadap motivasi belajar dalam kegiatan proses pembelajaran, kondisi lingkungan pembelajaran yang kondusif dapat meningkatkan gairah dan semangat belajar sehingga terjalin komunikasi interaktif baik antara mahasiswa dengan dosen maupun mahasiswa dengan mahasiswa yang dapat meningkatkan motivsi belajar mahasiswa, sehingga meningkatkan keaktifan mahasiswa dalam kegiatan pembelajaran dan menciptakan kegiatan belajar yang efektif.

Berdasarkan hasil uji koefisien determinasi pengaruh Lingkungan Pembelajaran Jarak Jauh terhadap Motivasi Intrinsik yaitu sebesar 31,3\%. Jika dilihat berdasarkan hasil penelitian sebelumnya memang lingkungan pembelajaran berpengaruh terhadap motivasi belajar tidak hanya saat Pembelajaran Jarak Jauh saja. Meskipun di era pandemi covid-19 kegiatan proses pembelajaran dilakukan secara daring, tidak menjadi hambatan untuk mahasiswa memiliki motivasi belajar yang tinggi meskipun masih terdapat kekurangankekurangan didalamnya, dengan pemanfaatan media online yang digunakan harus dioptimalkan sebagai jembatan untuk dosen dan mahasiswa agar tetap melaksanakan kegiatan pembelajaran secara optimal (Fitriyani et.al., 2020). Hal tersebut sejalan dengan hasil penelitian (Wahyuddin et,al., 2020) meskipun pembelajaran di era pandemi covid-19 ini dilaksanakan secara daring dengan keterbatsan ruang dan waktu, namun kendala-kendala yang ada dapat dihadapi dan diminimalisir dengan motivasi belajar mahasiswa yang cukup tinggi dengan semangar belajar mahasiswa secara mandiri sehingga kegiatan pembelajaran dapat terlaksanakan dengan baik. 
Jurnal Edumaspul, 5 (2), Year 2021 - 605

(Rizky Nurisriyani, Dian Alfia Purwandari, Sujarwo)

Berdasarkan hasil uraian pembahasan di atas, Lingkungan Pembelajaran Jarak Jauh berpengaruh terhadap Motivasi intrinsik karena di era pandemi sepeti ini kegiatan pembelajaran harus tetap dilaksnaakan dan pembelajaran jarak jauh menjadi alternatif yang dilakukan oleh masing-masing instansi pendidikan. Adanya lingkungan pembelajaran jarak jauh yang kondusif dapat mendorong mahasiswa untuk meningkatkan semangat dalam melaksanakan kegiatan belajar serta memberikan kesempatan yang luas untuk masing-masing mahasiswa agar dapat mengembangkan kompetensi yang dimilikinya secara kompeten, sehingga hal tersebut mempengaruhi motivasi intrinsik masingmasing mahasiswa dalam kegiatan pembelajaran

\section{SIMPULAN}

Berdasarkan hasil analisis data yang telah diuraikan, maka dapat ditarik kesimpulan terdapat pengaruh yang positif dan signifikan dari variabel Lingkungan Pembelajaran Jarak Jauh terhadap Motivasi Intrinsik dalam belajar mahasiswa program studi Pendidikan Ilmu Pengetahuan sosial angkatan 2018-2020. Hal tersebut dapat dilihat berdasarkan perolehan hasil uji-t dengan nilai $t_{\text {hitung }}>t_{\text {tabel }}(8,384>$ 1,975) yang berarti $\mathrm{HO}$ ditolak dan $\mathrm{H} 1$ diterima. Selain itu, diperkuat juga dengan perolehan hasil uji koefisien determinasi sebesar 31,3\%. Berdasarkan hasil penelitian yang telah dihitung dan diuraikan, adapun saran yang dapat peneliti berikan untuk peneliti selanjutnya atau yang hendak melakukan penelitian sejenis agar menambahkan variabel-variabel lain yang belum dimasukkan dalam penelitian ini.

\section{DAFTAR PUSTAKA}

Agustina, M. T., \& Danang, A. K. (2020). Motivasi Belajar Mahasiswa di Masa Pandemi Covid-19. Jurnal Psikologi Perseptual.

Aiyub. (2015). Motivasi Belajar Mahasiswa Selama Mengikuti Pendidikan Tinggi Keperawatan. Idea Nursing Journal, VI(2).

Akhtar, H. (2018). Cara Membuat Kategorisasi Data Penelitian dengan SPSS. Diambil dari
Semesta Psikometrika website: https://www.semestapsikometrika.com/ 2018/07/membuat-kategori-skor-skaladengan-spss.html

Argaheni, N. B. (2020). Sistematik Review: Dampak Perkuliahan Daring Saat Pandemi COVID-19 Terhadap Mahasiswa Indonesia. Placentum: Jurnal Ilmiah Kesehatan dan Aplikasinya, 8(2), 99. https://doi.org/10.20961/placentum.v8i 2.43008

Ayu, V. A. K. (2017). Tingkat Motivasi Belajar Siswa. Universitas Sanata Dharma.

Azis, A. L. (2017). Pengaruh Motivasi Intrinsik dan Motivasi Ekstrinsik Terhadap Prestasi Belajar Ekonomi Bisnis Kelas X Peserta Didik Kelas $X$ di SMKN 4 Makassar. Universitas Negeri Makassar.

Damanik, B. E. (2019). Pengaruh Fasilitas Dan Lingkungan Belajar Terhadap Motivasi Belajar. Jurnal Publikasi Pendidikan, 9.

Duli, N. (2019). Metode Penelitian Kuantitatif: Beberapa konsep dasar untuk penelitian skripsi dan analisis data dengan spss". Yogyakarta: Deepublish.

Elfian, Ariwibowo, P., \& Johan, R. S. (2017). Peran Pendidikan Tinggi Dalam Meningkatkan Minat Masyarakat Untuk Produktivitas Pendidikan. Sosio-E-Kons, 9(3), 200-216.

Emda, A. (2018). Kedudukan Motivasi Belajar Siswa Dalam Pembelajaran. Lantanida Journal, 5(2), https://doi.org/10.22373/lj.v5i2.2838

Farihin, M. (2014). Pengaruh Kondisi Mahasiswa dan Lingkungan Belajar Terhadap Motivasi Belajar Mahasiswa Program Studi Pendidikan Administrasi Perkantoran Fakultas Ekonomi Universitas Negeri Yogyakarta. Universitas Negeri Yogyakarta.

Fitriyani, Y., Fauzi, I., \& Sari, M. Z. (2020). Motivasi Belajar Mahasiswa Pada Pembelajaran Daring Selama Pandemik Covid-19. Profesi Pendidikan Dasar, 7(1), 121-132. https://doi.org/10.23917/ppd.v7i1.1097 3

Hakim, M., \& Mulyapradana, A. (2020). Pengaruh Penggunaan Media Daring dan Motivasi Belajar Terhadap Kepuasan Mahasiswa Pada Saat Pandemi Covid-19. 4(2), 154-160.

Handayani, R. D. (2017). Analisis Motivasi 
Intrinsik dan Ekstrinsik Mahasiswa Calon Guru Fisika. Jurnal Kependidikan, 1, 320333.

Koçoğlu, E., \& Tekdal, D. (2020). Analysis of distance education activities conducted during COVID-19 pandemic. 15(9), 536543.

https://doi.org/10.5897/ERR2020.4033

Mendari, A. S., \& Kewa, S. S. (2015). Motivasi Belajar Pada Mahasiswa. Jurnal Pendidikan Akuntansi Indonesia, XIII(2), 2.

ochtavia Yolanda Putri, C. (2020). Pembelajaran Daring, Efektif Gak Sih Buat Mahasiswa? Diambil dari egsaugm website:

https://egsa.geo.ugm.ac.id/2020/10/14/ pembelajaran-daring-efektif-gak-sihbuat-mahasiswa/

Ozerem, A., \& Akkoyunlu, B. (2015). Learning Environment Designed According to Learning Style and Its Effects on Mathematics Achievement. Eurasian Journal of Educational Research, (61), 6180.

Rista, K., \& Ariyanto, E. A. (2018). Pentingnya Pendidikan \& Meningkatkan Motivasi Belajar Anak. Jurnal Karya Pengabdian Dosen dan Mahasiswa, 01(02), 139-140. Diambil dari https://jurnal.untagsby.ac.id/index.php/abdikarya/article/vi ew $/ 2076$

Sugiyono. (2011). Metode penelitian Kuantitatif, Kualitatif, dan R\&D. Bandung: CV Alfabeta.

Sugiyono. (2013). Metode Penelitian Kuantitatif, Kualitatif dan R\&D. Bandung: CV Alfabeta.
Suwastika, I. W. K. (2017). Pengaruh Lingkungan Terhadap Motivasi Belajar Mahasiswa Stikom Bali. Jurnal Ilmiah Manajemen \& Akuntansi, 23(2), 75-88.

Utami, I. T. (2020). Pengaruh Motivasi Intrinsik Dan Ekstrinsik Mahasiswa Terhadap Pembelajaran Berbasis E-Learning Pada Mata Kuliah Pengetahuan Kesekretarisan Dan Praktik Kesekretarisan. Jurnal Sekretaris dan Administrasi (Serasi), 18.

Wahyuddin, Maharida, Jusriadi, E., \& Syafarrudin. (2020). Analysis of Motivation and How The Students Learn in Pandemic Analisis. Pedagogia:Jurnal Pendidikan, 9(2).

Walker, S., Özkök, A., \& Büyüköztürk, Ș. (2020). Reliability and validity of a Turkish version of the DELES. (October 2009), 0-32. https://doi.org/10.1007/s10984-0099060-0

\section{Profil Penulis}

Rizky Nurisriyani, lahir di Bogor 15 Juni 1999, merupakan seorang mahasiswi yang sedang menempuh Pendidikan Ilmu Pengetahuan Sosial jenjang Sarjana S1 di Universitas Negeri Jakarta. Bersama dengan Ibu Dr. Dian Alfia Purwandari,SE,M.Si yang merupakan dosen Program studi Pendidikan Ilmu Pengetahuan Sosial di Univeristas Negeri Jakarta dan Bapak Sujarwo S.Pd,M.Pd yang juga merupakan dosen program studi Pendidikan Ilmu Pengetahuan Sosial, Universitas Negeri Jakarta. Sekian profil singkat kami, Terima Kasih. 